\title{
VIABILIDADE DE Toxoplasma gondii EM CARNE OVINA APÓS TRATAMENTOS TÉRMICOS COM DIFERENTES TEMPERATURAS
}

(Toxoplasma gondii feasibility in lamb meat after thermal treatments at different temperatures)

Michelle Federle, Renata Arruda Ossani, Antonio Pereira de Souza, Anderson Barbosa de Moura, Paulo Henrique Exterchoter Weiss ${ }^{1}$

1Correspondência: pauloeweiss@gmail.com

RESUMO: A carne ovina possui grande potencial de transmissão do Toxoplasma gondii para os seres humanos e demais animais carnívoros, principalmente quando consumida crua ou mal passada. Com o objetivo de avaliar o efeito do resfriamento e congelamento sobre a viabilidade de cistos deste parasito em tecido muscular ovino, foram utilizados cortes cárneos de um cordeiro naturalmente infectado por $T$. gondii, com titulação de 1:256 na RIFI. Coração, fígado, diafragma e cérebro foram coletados em formol $10 \%$ para histopatológico. Coração e cortes musculares da paleta, costela e pernil foram usados nos tratamentos "in natura", resfriados a $7^{\circ} \mathrm{C}$ por $24 \mathrm{~h}$ e congelados a $-10^{\circ} \mathrm{C}$ por $12 \mathrm{~h}, 60 \mathrm{~h}$ e $120 \mathrm{~h}$. Após cada tratamento, foram coletados $50 \mathrm{~g}$ dos cortes e $16 \mathrm{~g}$ do coração para realização do bioensaio em camundongos e PCR. Após oito semanas, os camundongos foram eutanasiados e coletados órgãos para histopatológico, cérebro para "squash" e PCR e soro para RIFI. Foram positivos dois camundongos inoculados com amostras "in natura" e um inoculado com amostra após o resfriamento. Não foi possível verificar o efeito do congelamento sobe a viabilidade do T. gondii.

Palavras-chave: carne; cisto; ovino; Toxoplasma gondii; tratamento térmico

ABSTRACT: The lamb has great Toxoplasma gondii potential transmission to humans and other carnivorous animals, especially when consumed raw or undercooked. In order to evaluate the effect of cooling and freezing on the viability of cysts of this parasite in sheep muscle tissue, were used meat cuts of lamb naturally infected with T. gondii, with titer of 1: 256 at IFA. Heart, liver, diaphragm and brain were collected in $10 \%$ formalin for histopathological. Heart and muscle cuts from the palette, rib and ham were used in treatments "in natura", cooled to $7^{\circ} \mathrm{C}$ for 24 hours and frozen at $10^{\circ} \mathrm{C}$ for $12 \mathrm{~h}, 60 \mathrm{~h}$ and $120 \mathrm{~h}$. After each treatment were collected $50 \mathrm{~g}$ of heart cuts and $16 \mathrm{~g}$ for bioassay in mice and PCR. After eight weeks, the mice were euthanized and organs collected for histopathologic brain to "squash" and PCR and serum to IFA. Positive were two mice inoculated with samples "in natura" and an inoculated with sample after cooling. Could not verify the effect of freezing up the viability of $T$. gondii.

Key Words: cyst; lamb; meat; thermal treatment; Toxoplasma gondii 


\section{INTRODUÇÃO}

O Toxoplasma gondii é um protozoário com distribuição cosmopolita e em várias populações humanas no mundo, foi demonstrado $95 \%$ de pessoas infectadas com o parasito (CDC, 2015). Os ovinos, assim como suínos, caprinos e outros animais são fontes importantes de transmissão deste parasito para os seres humanos, através do consumo de carnes e vísceras contaminadas (Hill et al., 2005). Além disso, os seres humanos também podem se infectar através de oocistos em alimentos e água (Gattás et al., 2000), taquizoítos em leite (Chiari e Neves, 1984) ou congenitamente (Hill, 2005).

A soroprevalência do $T$. gondii nos rebanhos ovinos no mundo é variável, o que pode refletir o grau de contaminação da carne desta espécie. Pelo teste de RIFI, Fusco et al. (2007) no Sul da Itália encontraram $28,5 \%$ de soropositivos, já na região de Kars na Turquia pelo teste de ELISA, Mor e Arslan (2007) encontraram 95,7\% de positividade. No Brasil, também há essa diversificação de animais soropositivos o que pode ser verificado nos trabalhos de Moura et al. (2007) em Guarapuava no Paraná relataram ocorrência de $7 \%$ de ovelhas soropositivas no momento do abate; No estado do Rio de Janeiro Leite et al. (2014) encontraram 53,3\% de positividade; Guimarães et al. (2013) no sul da Bahia encontraram 32,2\% e Sakata et al. (2012) em Lages, Santa Catarina encontrou pela RIFI $(56,94 \%)$ e pelo ELISA $(42,50 \%)$ de positividade nos ovinos amostrados.

Nos ovinos, além de causar abortos e outros problemas reprodutivos, estes servem como fontes de infecção do parasito, se estes animais abrigarem cistos teciduais viáveis, para o homem e outros animais carnívoros (Dubey et al., 2005).
Segundo a FAO (2014) o consumo de carne ovina em 2012 foi de 13,7 milhões de toneladas no mundo e esta espécie possui grande potencial de transmissão do parasito através da carne demonstrado por Bonametti et al. (1997) onde descreveram a ocorrência de 17 casos de toxoplasmose aguda em pessoas após a ingestão de carne de carneiro crua, na forma de quibe, no estado do Paraná, Brasil.

Portanto, frente a grande possibilidade de transmissão do $T$. gondii através do consumo de carne e vísceras ovinas infectadas com 0 parasito sem tratamentos térmicos eficazes, reforça-se a importância de estudar a possibilidade de transmissão deste protozoário após tratamento pelo frio, preconizado pela legislação e utilizado nas indústrias de carnes.

\section{MATERIAL E MÉTODOS}

Para realização do experimento, foi utilizada uma cordeira com aproximadamente sete meses de idade, mestiça, mas com predominância da raça Crioula, proveniente de um lote de 12 animais com faixa etária semelhante, criados semi-extensivamente no campus do Centro de Ciências Agroveterinárias do CAV/UDESC na cidade de Lages, SC, Brasil.

Esse animal apresentava uma titulação de 1:256 para $T$. gondii avaliado pela RIFI. A cordeira foi abatida em um frigorífico conforme as normas do Regulamento de Inspeção Industrial e Sanitária de Produtos de Origem Animal - RIISPOA e utilizado para as demais etapas do experimento.

Com o intuito de avaliar a viabilidade do $T$. gondii, foi realizado bioensaio em 42 camundongos albinos Swiss, livres de doenças, nascidos no biotério do CAV/UDESC, mas com pais vindos do biotério da Universidade Federal de Santa Catarina - UFSC. Os 
Toxoplasma gondii feasibility in lamb meat after thermal treatments at different temperatures

camundongos utilizados tinham seis meses de idade, e permaneceram até a realização do experimento em caixas separados por sexo, com água e ração a vontade.

\section{Coleta das amostras do ovino}

Após abate do animal, primeiramente foi coletado amostras do cérebro, coração, diafragma e fígado em formol $10 \%$ para realização do histopatológico para pesquisa do $T$. gondii ou outras alterações que por ventura estivessem presentes.

Fragmentos do diafragma e do fígado também foram coletados em recipientes estéreis e mantidos refrigerados para posterior realização da PCR à procura de DNA do parasito.

Para realização do bioensaio e PCR das amostras do cérebro, coração e tecido muscular dos cortes da paleta, costela e pernil, foram coletadas $50 \mathrm{~g}$ de cada, em cada tratamento proposto, exceto o coração, que foram coletados $16 \mathrm{~g}$ do órgão em cada tratamento, devido ao peso reduzido do órgão. 0 tecido cerebral foi coletado somente "in natura", pois, só serviu como marcador da presença de cistos. As amostras foram coletadas e mantidas em recipientes estéreis, refrigeradas, separadas e identificadas, até a chegada ao laboratório de Parasitologia e Doenças Parasitárias do CAV/UDESC.

No músculo e coração "in natura" e resfriados, as coletas foram realizadas através de uma faca, lavada a cada amostra em água a $72^{\circ} \mathrm{C}$. Na carne e coração após o congelamento, as coletas foram realizadas através de serra-fita, disponibilizada pelo próprio estabelecimento, coletando amostras do interior da peça e da extremidade, para uniformidade das coletas.

Todos os tratamentos foram desenvolvidos no frigorífico, específico para o abate desta espécie, seguindo todas as normas estabelecidas pelo RIISPOA de 1952.

\section{Tratamentos térmicos}

Foram 0 total de cinco tratamentos, sendo estes:

- "In natura": Logo após o abate, amostras cruas;

- Após o resfriamento: Após o abate, a carcaça inteira juntamente com - coração foi para a câmara de resfriamento por $24 \mathrm{~h}$ a $7^{\circ} \mathrm{C}$, e após este período foi realizada a segunda coleta;

- Congelamento a $-10^{\circ} \mathrm{C}$ por $12 \mathrm{~h}$ : Após a coleta do resfriamento, a carcaça foi desmembrada, e os cortes do estudo - paleta, costela, pernil juntamente com o coração foram embalados separadamente em papel filme, identificados e acondicionados na câmara de congelamento a $-10^{\circ} \mathrm{C}$, e após $12 \mathrm{~h}$ foi realizada a primeira coleta do congelamento;

- Congelamento a $-10^{\circ} \mathrm{C}$ por $60 \mathrm{~h}$ : Após a coleta com $12 \mathrm{~h}$ de congelamento, nova coleta foi realizada com $60 \mathrm{~h}$ de congelamento dos mesmos cortes e do coração;

- Congelamento a $-10^{\circ} \mathrm{C}$ por $120 \mathrm{~h}$ : ao totalizar 120 horas de congelamento, foi realizada a última coleta dos cortes musculares e do coração.

\section{Digestão péptica das amostras}

A amostra de tecido cerebral, e as amostras do coração e dos cortes da paleta, costela e pernil do ovino, após cada tratamento, foram digeridas através da adaptação da técnica descrita por Dubey (1998). Após a digestão das amostras, estas foram utilizadas para bioensaio em camundongos e para PCR.

Resumidamente, foram retiradas a gordura e tecido conectivo de todas as amostras, permanecendo somente tecido muscular. No caso do tecido cerebral, utilizou-se a amostra inteira. As amostras foram picadas e trituradas em triturador doméstico com $125 \mathrm{~mL}$ de 
solução fisiológica a 0,9\%. Retirado do misturador as amostras trituradas foram passadas para um recipiente de vidro estéril, e ao misturador foi adicionado $125 \mathrm{~mL}$ de solução fisiológica para limpeza do mesmo e então misturado as amostras trituradas, totalizando $250 \mathrm{~mL}$. Foi preparado uma solução de ácido clorídrico e pepsina a temperatura de $37^{\circ} \mathrm{C}$ que continha em $500 \mathrm{~mL}$ de água ultrapura, $7 \mathrm{~mL} \mathrm{HCl}$ a $37 \%, 2,6 \mathrm{~g}$ de pepsina $1: 10000,5,0 \mathrm{~g}$ de $\mathrm{NaCl}$ (P.M. $58,44)$. O homogeneizado que estava a temperatura ambiente foi pré-aquecido a $37^{\circ} \mathrm{C}$ em estufa e adicionado $250 \mathrm{~mL}$ da solução de ácido clorídrico e pepsina e incubada a $37^{\circ} \mathrm{C}$ em incubadora Shaker, com agitação durante 60 minutos. Após, as amostras foram filtradas em duas camadas de gaze estéreis para outro recipiente estéril e distribuído entre tubos cônicos de $50 \mathrm{~mL}$ e centrifugados a $1200 \mathrm{rpm}$ por 10 minutos. O sobrenadante foi desprezado e o sedimento ressuspenso em $20 \mathrm{~mL}$ de PBS pH 7,2. O homogeneizado foi transferido para um único tubo $\mathrm{e}$ neutralizado com $15 \mathrm{~mL}$ de solução de bicarbonato de sódio a 1,2\% e pH 8,3. Foi realizada nova centrifugação a $1200 \mathrm{rpm}$ por 10 minutos e o sobrenadante resultante desprezado e ao sedimento adicionado $5 \mathrm{~mL}$ de solução fisiológica a $0,9 \%$ contendo $1000 \mathrm{U}$ de penicilina e $100 \mu \mathrm{g}$ de estreptomicina por $\mathrm{mL}$.

\section{Bioensaio em camundongos}

Após a digestão péptica das amostras, estas foram utilizadas para inoculação nos camundongos, por via intraperitoneal, sendo $1 \mathrm{~mL}$ em cada animal. A digestão péptica que restava, foi congelada a $-20^{\circ} \mathrm{C}$ até a realização da PCR. Foram utilizados dois animais por amostra em cada tratamento e estes foram divididos em cinco grupos correspondentes a cada tratamento proposto:
-Grupo 1: 10 camundongos tratamento "in natura";

-Grupo 2: 8 camundongos tratamento após resfriamento por $24 \mathrm{~h}$ a $7^{\circ} \mathrm{C}$;

- Grupo 3: 8 camundongos tratamento após congelamento a $-10^{\circ} \mathrm{C}$ por 12 horas;

-Grupo 4: 8 camundongos tratamento após congelamento a $-10^{\circ} \mathrm{C}$ por $60 \mathrm{~h}$;

- Grupo 5: 8 camundongos tratamento após congelamento a $-10^{\circ} \mathrm{C}$ por 120h;

No grupo 1 há dois animais a mais que os demais grupos pois foram os que receberam a digestão do tecido cerebral do ovino. Cada caixa correspondia a um tratamento e todos dentro do compartimento tinham o mesmo sexo e recebiam água e ração à vontade. As caixas eram limpas duas vezes por semana, e após inoculação os camundongos foram avaliados diariamente visando observar a manifestação de sinais clínicos de toxoplasmose aguda (apatia, anorexia, depressão, enoftalmia e pelos arrepiados).

Após completarem oito semanas de inoculação, os camundongos foram eutanasiados. Amostras de diferentes órgãos (coração, pulmão, músculo esquelético, fígado, baço e rim) e tecido muscular da coxa foram coletadas e armazenadas em frascos com solução de formol a $10 \%$ para realização de exame histopatológico para a pesquisa do agente. Destes animais também foi colhido sangue para obtenção do soro para posterior pesquisa de anticorpos contra $T$. gondii pela RIFI.

Fragmentos de cérebro ( 3 a $5 \mathrm{~mm}^{2}$ ) foram comprimidos entre lâmina e lamínula (squash) para a pesquisa de cistos. Amostras de tecido cerebral também foram coletadas em microtubos e congeladas a $-20^{\circ} \mathrm{C}$ para posterior extração de DNA e realização da PCR. Foram considerados infectados com $T$. 
gondii os camundongos nos quais estágios do parasito foram encontrados em seus tecidos ou aqueles positivos no teste de RIFI ( $\geq 1: 16)$.

PCR das amostras musculares e vísceras do ovino "in natura" e após o resfriamento e o congelamento e em amostras cerebrais dos camundongos inoculados

As amostras que estavam congeladas após a digestão péptica, foram submetidas à extração de DNA. As amostras do fígado e do diafragma do ovino, assim como o tecido cerebral dos camundongos por não terem sido digeridas, foram expostas ao homogeneizador de tecidos para posterior extração do DNA. Foram utilizadas cinco amostras do fígado e quatro de diafragma de aproximadamente $600 \mathrm{mg}$ cada, e adicionado $500 \mu \mathrm{L}$ de tampão TEN sem SDS (Tris $\mathrm{HCl} 20 \mathrm{mM}$, EDTA $50 \mathrm{mM}$, $\mathrm{NaCl} 200 \mathrm{mM}$ ) em cada amostra. Já ao tecido cerebral dos camundongos, em cada microtubo foram adicionados $750 \mu \mathrm{L}$ de TEN sem SDS.

A extração de DNA foi realizada pela técnica do fenol clorofórmio, adaptada da metodologia descrita por Sambrook e Russell (2001). Após a extração, foi mensurado a quantidade de DNA presente na amostra no aparelho NanoDrop $2000 \AA$ para realização da PCR. Os componentes da PCR foram: 1 $\mu \mathrm{L}$ DNA extraído; 1 a $2 \mathrm{U}$ de Platinum Taq; $300 \mu \mathrm{M}$ de um mix de DNTP's; $1,5 \mathrm{mM}$ de $\mathrm{MgCl}_{2} 25 \mathrm{mM} ; 4,5$ pmol de cada Primer; Tampão 10 vezes; Água ultrapura estéril até completar $50 \mu \mathrm{l}$ totais no tubo; Primer SAG2.F4 (59GCTACCTCGAACAGGAACAC39); Primer SAG2.R4 (59GCATCAACAGTCTTCGTTGC39). A amplificação do DNA do parasito foi feita em 30 ciclos em um termociclador, usando as condições mostradas na Tabela 1.

Tabela 1 - Fases e temperaturas utilizadas na Polymerase Chain Reaction - PCR
\begin{tabular}{lcc} 
& & \\
\hline Fase & Tempo & Temperatura \\
\hline 1.Desnaturação inicial & 5 minutos & $95^{\circ} \mathrm{C}$ \\
2.Desnaturação & 30 segundos & $94^{\circ} \mathrm{C}$ \\
3.Anelamento & 40 segundos & $65^{\circ} \mathrm{C}$ \\
4. Extensão inicial & 1 minuto & $72^{\circ} \mathrm{C}$ \\
5.Ciclos (etapas 2 a 4) & 30 ciclos & \\
6. Extensão final & 10 minutos & $72^{\circ} \mathrm{C}$ \\
7.Manutenção & 8 & $4^{\circ} \mathrm{C}$ \\
\hline
\end{tabular}

Os produtos da PCR foram submetidas à eletroforese em gel de agarose padrão baixa eletroendoosmose (EEO) à 1,5\%. Foi utilizado o DNA de taquizoítos da cepa VEG de T. gondii como controle positivo e a mistura de todos os componentes citados, exceto o DNA como controle negativo da PCR. Como marcador de peso molecular foi utilizado o de 100pb.

\section{RESULTADOS}

Nas amostras do tecido cerebral, diafragma, fígado e coração do ovino submetidos ao exame histopatológico, não foram encontrados cistos do $T$. gondii nem alterações significativas nestes órgãos.

$\mathrm{Na}$ pesquisa de cisto de $T$. gondii no tecido cerebral dos camundongos, pela técnica de "squash", somente o animal inoculado com amostra da costela após o resfriamento a $7^{\circ} \mathrm{C}$ por 24 horas apresentou cisto (Figura 1). Na RIFI, dois camundongos foram positivos, um inoculado com amostra da costela "in natura" e outro com tecido muscular da costela após o resfriamento, ambos apresentando titulação de 1:64. $\mathrm{Na}$ Tabela 2 estão os resultados do bioensaio em camundongos. 


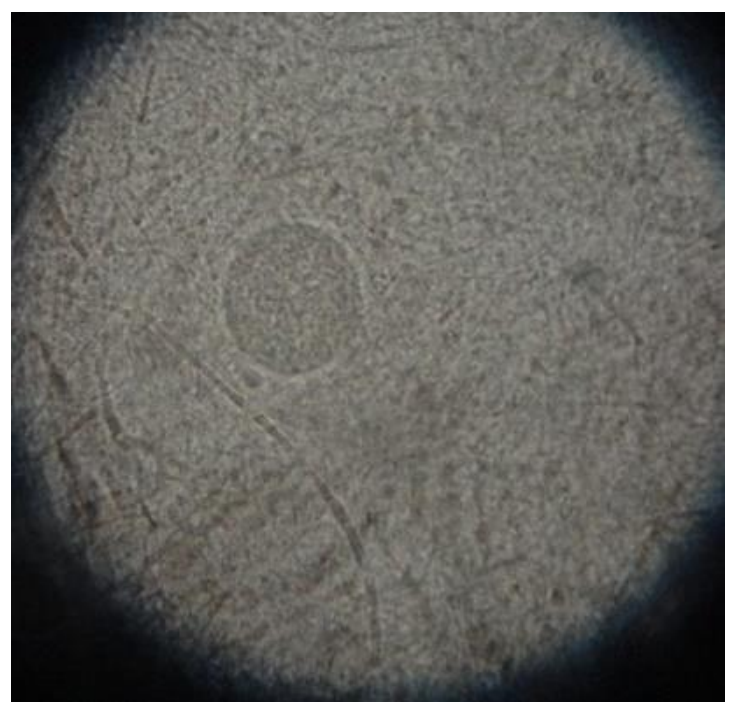

Figura 1 - Cisto tecidual de Toxoplasma gondii, em tecido cerebral de camundongo inoculado com tecido muscular proveniente do corte da costela resfriada a $7^{\circ} \mathrm{C}$ por $24 \mathrm{~h}$ de ovino com sorologia positiva para $T$. gondii. Técnica "squash". Aumento de 400x.

Tabela 2 - Resultados da PCR e "squash" de cérebro de camundongos e histopatológico e do coração, pulmão, figado, baço, rins e tecido esquelético da coxa de camundongos inoculados com tecido muscular esquelético, cardíaco e cerebral de tratamentos térmicos

\begin{tabular}{|c|c|c|c|c|c|}
\hline Tratamentos & Cortes & RIFI & $\begin{array}{l}\text { PCR do } \\
\text { cérebro }\end{array}$ & $\begin{array}{l}\text { Squash } \\
\text { cérebro }\end{array}$ & Histopatológico \\
\hline "In natura" & $\begin{array}{l}\text { Paleta } \\
\text { Costela } \\
\text { Pernil } \\
\text { Coração } \\
\text { Cérebro }\end{array}$ & $\begin{array}{l}A^{*}=\mathrm{Neg} \\
B^{*}=N C \\
A=1: 64 \\
B=N e g \\
A=N e g \\
B=N e g \\
A=N e g \\
B=N e g \\
A=N e g \\
B=N e g\end{array}$ & $\begin{array}{l}A=P o s \\
B=N e g \\
A=N e g \\
B=N e g \\
A=N e g \\
B=N e g \\
A=N e g \\
B=N e g \\
A=N e g \\
B=N e g\end{array}$ & $\begin{array}{l}A=N e g \\
B=N C \\
A=N e g \\
B=N e g \\
A=N e g \\
B=N e g \\
A=N e g \\
B=N e g \\
A=N e g \\
B=N e g\end{array}$ & $\begin{array}{l}A=N e g \\
B=N C \\
A=N e g \\
B=N e g \\
A=N e g \\
B=N e g \\
A=N e g \\
B=N e g \\
A=N e g \\
B=N e g\end{array}$ \\
\hline $\begin{array}{l}\text { Resfriamento a } \\
7^{\circ} \mathrm{C} \text { por } 24 \mathrm{~h}\end{array}$ & $\begin{array}{l}\text { Paleta } \\
\text { Costela } \\
\text { Pernil } \\
\text { Coração }\end{array}$ & $\begin{array}{l}A=\mathrm{Neg} \\
B=\mathrm{Neg} \\
A^{*}=1: 64 \\
B=\mathrm{Neg} \\
A=\mathrm{Neg} \\
B=\mathrm{Neg} \\
A=\mathrm{Neg} \\
B=\mathrm{Neg}\end{array}$ & $\begin{array}{l}A=\mathrm{Neg} \\
B=\mathrm{Neg} \\
A=\mathrm{Neg} \\
B=\mathrm{Neg} \\
A=\mathrm{Neg} \\
B=\mathrm{Neg} \\
A=\mathrm{Neg} \\
B=\mathrm{Neg}\end{array}$ & $\begin{array}{l}A=\mathrm{Neg} \\
B=\mathrm{Neg} \\
A=\mathrm{Pos} \\
B=\mathrm{Neg} \\
A=\mathrm{Neg} \\
B=\mathrm{Neg} \\
A=\mathrm{Neg} \\
B=\mathrm{Neg}\end{array}$ & $\begin{array}{l}A=N e g \\
B=N e g \\
A=C ., P ., M . \\
B=N e g \\
A=N e g \\
B=N e g \\
A=N e g \\
B=N e g\end{array}$ \\
\hline
\end{tabular}

\section{Neg. Negativo
Pos. P Positvo

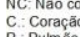 \\ M. . . . Mússulo esquelético \\ $A=$ Camundongos 1
$B=$ Camundongo 2}

Três camundongos morreram durante o experimento, mas nenhum apresentou sinais clínicos que indicasse toxoplasmose. As coletas de cada animal que morreu antes das oito semanas podem ser visualizadas na Tabela 2.

De todas as amostras submetidas a PCR, observou-se presença de DNA compatível com $T$. gondii apenas nos tecidos do cérebro e da costela "in natura" do ovino. $\mathrm{Na}$ PCR do tecido cerebral dos camundongos, 0 animal inoculado com amostra da paleta "in natura" foi positivo. Os resultados da
PCR podem ser observados na Figura 2.

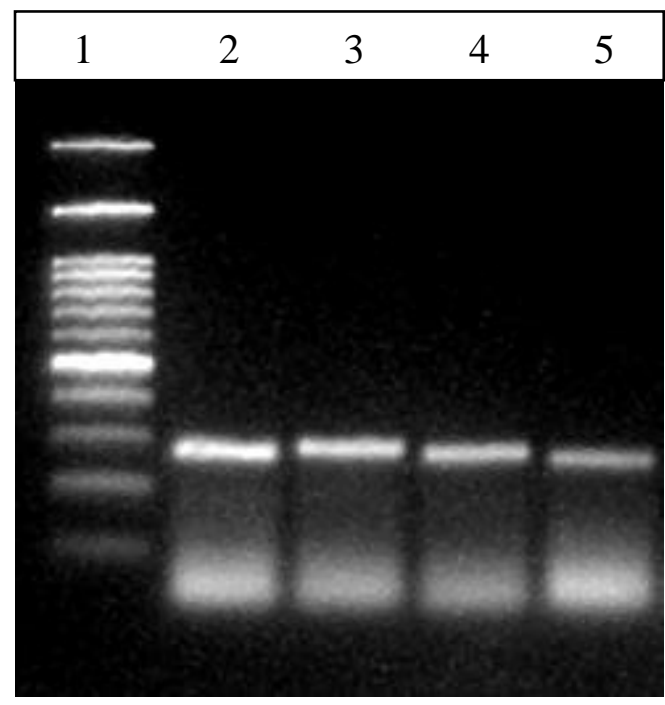

Figura 2 - Eletroforese em gel de agarose $1,5 \%$. Visualização das bandas (340 pb) de DNA de Toxoplasma gondii em amostras de tecido e vísceras de ovino com titulação de 1:256 e de camundongo inoculado com tecido ovino $[1=$ padrão de molecular (100bp); 2 = amostra positiva de cérebro do ovino; 3 = amostra positiva do corte da costela "in natura"; 4 = amostra positiva de cérebro de camundongo inoculado com 0 corte da paleta após o resfriamento a $7^{\circ} \mathrm{C}$ por $24 \mathrm{~h} ; 5$ = controle positivo (cepa VEG de T. gondii)].

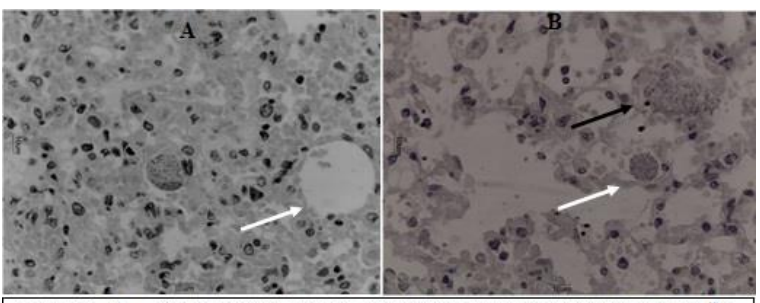

Figura 3 - Cisto tecidual de Toxoplasma gondii em pulmão, proveniente do camundongo inoculado com o corte da costela resfriada a $7^{\circ} \mathrm{C}$ por $24 \mathrm{~h}$ de ovino positiva sorologicamente. A - Cisto com aproximadamente $20 \mu \mathrm{m} \times 18 \mu \mathrm{m}$ (se ta branca). B - Cisto com aproximadamente $15 \mu \mathrm{m} \times 15 \mu \mathrm{m}$ (seta branca) e cisto rompido (seta preta). H. E. Aumento de 400x. 


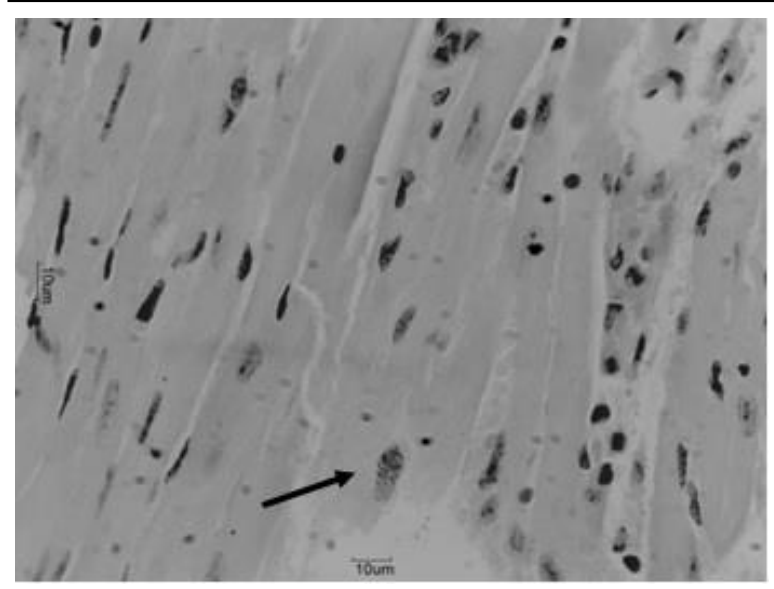

Figura 4 - Cisto tecidual de Toxoplasma gondii em tecido cardíaco (seta), proveniente do camundongo inoculado com o corte da costela resfriada a $7^{\circ} \mathrm{C}$ por $24 \mathrm{~h}$ de ovino positivo sorologicamente. H. E. Aumento de 400x.

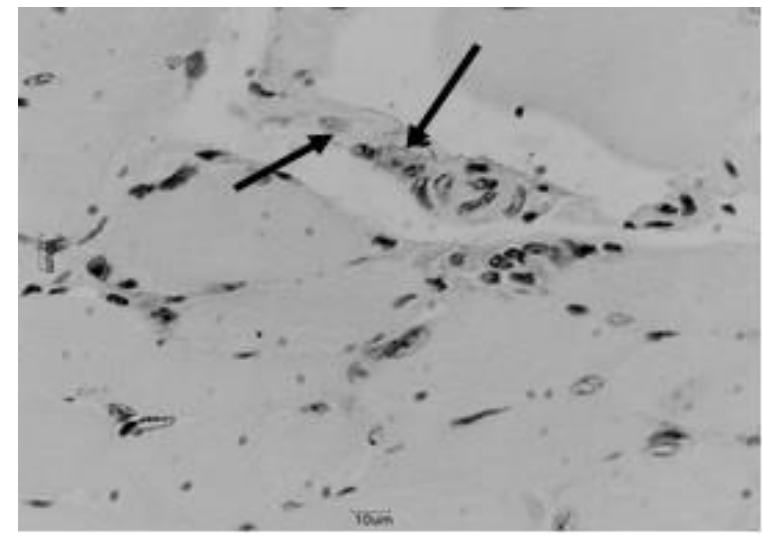

Figura 5 - Cistos teciduais de Toxoplasma gondii em tecido muscular esquelético da coxa (setas), proveniente do camundongo inoculado com o corte da costela resfriada a $7^{\circ} \mathrm{C}$ por $24 \mathrm{~h}$ de ovino positivo sorologicamente. H. E. Aumento de 400x.

$\mathrm{Na}$ tabela 3 estão descriminados a quantidade de animais positivos por grupo e a percentagem correspondente. Sendo que no grupo dos camundongos inoculados com tecido muscular "in natura" foi onde obteve-se o maior número de animais positivos para $0 T$. gondii.

\begin{tabular}{lcccc}
$\begin{array}{c}\text { Tabela } 3 \\
\text { utilizados }\end{array}$ & \multicolumn{5}{c}{ Camundongos positivos por grupo e em relação ao total de animais } \\
\hline & $\begin{array}{c}\text { Camundongos } \\
\text { por grupo }\end{array}$ & $\begin{array}{c}\text { Total de positivos } \\
\text { por grupo }\end{array}$ & $\begin{array}{c}\text { \% de positivos } \\
\text { por grupo }\end{array}$ & $\begin{array}{c}\text { \% de positivos em } \\
\text { relação ao total }\end{array}$ \\
\hline Grupo 1 & 10 & 2 & 20 & 4,76 \\
Grupo 2 & 8 & 1 & 12,5 & 2,38 \\
Grupo 3 & 8 & 0 & 0,0 & 0,0 \\
Grupo 4 & 8 & 0 & 0,0 & 0,0 \\
Grupo 5 & 8 & 0 & 0,0 & 0,0 \\
\hline TOTAL & 42 & 3 & - & 7,14
\end{tabular}

\section{DISCUSSÃO}

$\mathrm{Na}$ carne "in natura", como demonstrado por outros autores como Bonametti et al. (1997) com carne ovina e Choi et al. (1997) com carne suína, foi encontrado o parasito viável. Este fato reforça a necessidade de utilizar medidas profiláticas antes do consumo, uma vez que o parasito não é visível a olho nu e este fato pode favorecer a infecção por ingestão.

O T. gondii permaneceu viável na musculatura do ovino mesmo após o resfriamento a $7^{\circ} \mathrm{C}$ por $24 \mathrm{~h}$. Resultados semelhantes foram encontrados por ElNawawi et al. (2008), que após contaminarem duas ovelhas, moldaram duas amostras de $50 \mathrm{~g}$ cada, de tecido muscular em cubos de $5 \mathrm{~cm}^{3}$ e submeteram à temperatura de $5^{\circ} \mathrm{C}$ durante cinco dias e os cistos se mantiveram viáveis.

$\mathrm{Na}$ temperatura de congelamento, não foi observado positividade em nenhum dos testes realizados, e isso pode ser pelo fato de o congelamento ter inativado 0 protozoário, assim como Lundén e Uggla (1992) relataram que 0 congelamento a $-20^{\circ} \mathrm{C}$ durante $54 \mathrm{~h}$ e em seguida descongelada a $+4^{\circ} \mathrm{C}$, era capaz de matar o parasito em carne ovina, processada de forma semelhante a este estudo. Para determinar se 0 congelamento nesta temperatura foi realmente eficaz na inativação de cistos teciduais do $T$. gondii, devem ser feitos novos estudos com mais ovinos e camundongos, para poder direcionar um 
melhor tratamento da carne na indústria, para que a mesma possa ser consumida seguramente pela população.

Dubey (2008) citou que cistos teciduais do parasito foram encontrados em muitas partes comestíveis de ovelhas e alguns surtos em seres humanos já foram descritos após o consumo da carne destes animais, principalmente na forma de quibe (De Silva, et al., 1984, Bonametti et al., 1997, Renoiner et al., 2007).

El-Nawawi et al. (2008) demonstraram, através do bioensaio que o congelamento inativou os cistos teciduais do $T$. gondii, em tecido muscular de ovinos após dois dias a $10^{\circ} \mathrm{C}$ embora a $-20^{\circ} \mathrm{C}$ os cistos se mantiveram viáveis por um dia. No entanto o congelamento foi de cubos com $5 \mathrm{~cm}^{3}$. Provavelmente em cortes mais espessos seja necessário um período maior de congelamento, como já citado.

O tecido cerebral foi utilizado somente no tratamento "in natura", pois este órgão é o que apresenta maior predileção em apresentar cistos teciduais do T. gondii, como já descritos por Dubey (1997) que estudou a persistência e distribuição de cistos teciduais em gatos e ratos. $O$ autor confirmou a predileção do parasito por órgãos como cérebro, coração e músculo esquelético e que em roedores os cistos teciduais de $T$. gondii são mais comumente encontrados no cérebro, resultados semelhantes foram encontrados neste estudo.

Ao observar a Tabela 3 verificase que o grupo de maior risco em desenvolver a toxoplasmose foi o grupo 1, ou seja, com carne ovina sem nenhum tipo de tratamento térmico. $\mathrm{E}$ do total de animais utilizados, 7,14\% foram positivos em algum dos testes utilizados. Isso demonstra que 0 consumo de carne ovina, possui grande potencial de transmissão do $T$. gondii para quem a consumir.
No exame histopatológico do fígado, coração, diafragma e cérebro do ovino, não foi observada positividade, mas nos tecidos dos camundongos sim. Isso pode indicar que quando se trabalha com animais de médio porte, o histopatológico não é sensível para encontrar cistos do $T$. gondii, ou que o resultado positivo depende da quantidade de cistos presentes nos órgãos. Esteban-Redondo e Innes (1998) pela PCR encontraram parasitos no cérebro, no coração e no músculo grácil de ovinos infectados artificialmente com oocistos e no histopatológico, todas as amostras foram negativas, reforçando que 0 histopatológico não é um exame sensível na pesquisa deste parasito em ovinos.

Tanto a PCR quanto o bioensaio foram capazes de detectar a presença do parasito no presente estudo, todavia, a PCR somente mostra a presença do DNA do agente nas amostras. A viabilidade, pode ser demonstrada pelo bioensaio, por isto o uso das duas técnicas otimiza os resultados. A diferença entre a sensibilidade das técnicas do bioensaio e da PCR foi demonstrada por Da Silva; Langoni (2001) e Tsutsui et al. (2007). No presente estudo, não se pode demonstrar qual técnica foi mais eficaz, pelo fato de se ter utilizado um único animal para o experimento.

Yildiz et al. (2014) na Turquia, estabeleceram uma relação entre sorologia e a presença de cistos teciduais em 100 ovinos naturalmente infectados. Encontraram 46 das 100 ovelhas com presença do cisto, e o tecido mais prevalente foi o cérebro com 36 ovelhas, seguido do intercostal em 15, perna e diafragma em 14, e masseter e língua em nove. Os cistos foram mais prevalentes em ovelhas com um título elevado de IgG e também detectado nos tecidos dos animais de até um ano de idade (55,5\%). O estudo 
destes autores justifica o fato de se ter utilizado cordeiro, com titulação de 1:256 neste experimento, para aumentar as chances de encontrar cistos teciduais ou viscerais de T. gondii.

Não foi possível $o$ isolamento do $T$. gondii no coração por nenhuma das técnicas utilizadas, provavelmente por ter sido coletada amostra de apenas um ovino no experimento ou porque este órgão não estava parasitado. Porém, Dumètre et al. (2006) isolaram o parasito em oito de 30 corações de ovinos soropositivos.

Um camundongo inoculado com o corte da paleta "in natura" apresentou o parasito no tecido cerebral na técnica da PCR, porém, sem soroconversão, assim como um camundongo foi positivo na RIFI com título de 1:64 e não apresentou positividade em nenhum dos outros testes. Isto já foi visualizado em outros trabalhos como de Trevisani et al. (2013), onde camundongos com cistos cerebrais foram soronegativos para o $T$. gondii. Assim, mesmo animais com resultados negativos na sorologia podem estar infectados e apresentar cistos teciduais do protozoário e este fato pode ser explicado pela variação biológica dos animais para produção de anticorpos.

A Portaria $\mathrm{n}^{\circ} \mathrm{0} 711$, de $1^{\circ} \stackrel{\mathrm{o}}{\mathrm{de}}$ Novembro de 1995 utilizada como base para desenvolvimento dos tratamentos de congelamento cita que a temperatura deve ser de $-18^{\circ} \mathrm{C}$ para a carne, a câmara fria da indústria estava ligada nesta temperatura, porém a temperatura real medida no interior da mesma foi de $-10^{\circ} \mathrm{C}$, pois a temperatura real dentro da câmara depende da quantidade carne armazenada na mesma.

\section{CONCLUSÃO}

Não foi possível detectar a presença do $T$. gondii no pernil, paleta, costela e no coração após o congelamento $\mathrm{a}-10^{\circ} \mathrm{C}$, por 12,60 e 120 horas, em ovino naturalmente infectado $(\mathrm{RIFI}=1: 256)$.

\section{NOTAS INFORMATIVAS}

Estudo aprovado pelo Comitê de Ética em Experimentação Animal (CETEA) da Universidade do Estado de Santa Catarina (UDESC), sob o protocolo $\mathrm{n}^{\circ}$ 01.01.15.

\section{REFERÊNCIAS}

BONAMETTI, A.M.; PASSOS, J. do N.; DA SILVA, E.M.K. et al. Surto de toxoplasmose aguda transmitida através da ingestão de carne crua de gado ovino. Revista da Sociedade Brasileira de Medicina Tropical, v.30, n.1, p. 2125, 1997.

Centers for Disease Control and Prevention - CDC. "Toxoplasmosis", 2015. Disponível em: < http:// http://www.cdc.gov/parasites/toxoplasm osis>. Acesso em 13/08/2015.

CHIARI, C.A.; NEVES, D.P. Toxoplasmose humana adquirida através da ingestão de leite de cabra. Memórias Instituto Oswaldo Cruz, vol.79, n.3, p. 337-340, 1984.

CHOI, W.Y.; NAM, H.W.; KWAT, N.H. et al. Foodborne outbreaks of human toxoplasmosis. The Journal of Infectious Diseases, v. 175 , n. 5 , p. 1280-1282, 1997. 
DA SILVA, A.V.; LANGONI, H. The detection of Toxoplasma gondii by comparing cytology, histopathology, bioassay in mice, and the polymerase chain reaction (PCR). Veterinary Parasitology, v. 97, n. 3, p. 191-198, 2001.

DE SILVA, L.M. MULCAHY, D.L.; KAMATH, K.R. A family outbreak of toxoplasmosis: a serendipitous finding. Journal of Infection, v. 8, p. 163-167, 1984.

DUBEY, J.P. Tissue cyst tropism in Toxoplasma gondii: a comparison of tissue cyst formation in organs of cats, and rodents fed oocysts. Parasitology, v. 115 , n.1, p. 15-20, 1997.

DUBEY, J.P. Refinement of pepsin digestion method for isolation of Toxoplasma gondii from infected tissues. Veterinary Parasitology, v. 74, p. 75-78, 1998.

DUBEY J.P.; HILL, D.E.; JONES, J.L. et al. Prevalence of viable Toxoplasma gondii in beef, chicken, and pork from retail meat stores in the United States: Risk assessment to consumers. Journal of Parasitology, v. 91 , n. 5, p. 10821093, 2005.

DUBEY, J.P.; SUNDAR, N.; HILL,D.E. et al. High prevalence and abundant atypical genotypes of Toxoplasma gondii isolated from lambs destined for human consumption in the USA. International Journal for Parasitology, v. 38, n. 8-9, p. 999-1006, 2008.

DUMÈTRE, A.; AJZENBERG, D.;ROZETTE, L. et al. Toxoplasma gondii infection in sheep from HauteVienne, France: Seroprevalence and isolate genotyping by microsatellite analysis. Veterinary Parasitology, v. 142, n. 3-4, p. 376-379, 2006.

EL-NAWAWI, F.A.; SHAAPAN, R.M.; TAWFIK, M.A. Methods for inactivation of Toxoplasma gondii cysts in meat and tissues of experimentally infected sheep.
Foodborne Pathogens and Disease, v. 5, n. 5, p. 687 - 690, 2008.

ESTEBAN-REDONDO, I.; INNES, E.A. Detection of Toxoplasma gondii in tissues of sheep orally challenged with diferent doses of oocysts. International Journal for Parasitology, v. 28, n.9, p. 1459-1466, 1998.

Food and Agriculture Organization of the United Nations - FAO. "Meat Consumption", 2014. Disponível em: http://www.fao.org/ag/againfo/themes/en /meat/background.html. Acesso em 05/12/2014.

FUSCO, G.; RINALDI, L. GUARINO, A. et al. Toxoplasma gondii in sheep from the Campania region (Italy). Veterinary Parasitology, v.149, n. 3-4, p. 271-274, 2007.

GATTÁS, V.L.; NUNES, E.M.; SOARES, A.L.B. et al. Acute toxoplasmose outbreak at campus of the University of São Paulo related to food or water oocyst contamination. In: ANNALS OF THE INTERNATIONAL CONFERENCE ON EMERGING INFECTIOUS DISEASES., Atlanta, 2000. Anais... Geórgia, Atlanta, 135.

GUIMARÃES, L.F.; BEZERRA, R.A. ROCHA, D. de S. et al. Prevalence and risk factors associated with antiToxoplasma gondii antibodies in sheep from Bahia state, Brazil. Brazilian Journal of Veterinary Parasitology, v. 22, n.2, p. 220-224, 2013.

HILL, D. E.; CHIRUKANDOTH, S.; DUBEY, J. P. Biology and epidemiology of Toxoplasma gondii in man and animals. Animal Health Research Reviews, v. 6, n. 1, p. 41-61, 2005.

LEITE R. C.K.; DE OLIVEIRA, F.C.; FRAZÃO-E, T. et al. Occurrence and risk factors associated to Toxoplasma gondii infection in sheep from Rio de Janeiro, Brazil. Tropical Animal Health and Production, v. 46, n.8, p.14631466, 2014. 
LUNDÉN, A.; UGGLA, A. Infectivity of $T$. gondii in mutton following curing, smoking, freezing or microwave cooking. International Journal of Food Microbiology, v.15, n. 3-4, p.357-363, 1992.

MOR, N.; ARSLAN, M.O. Kar yöresindeki koyunlarda Toxoplasma gondii nin seroprevalansi. Kafkas Üniversitesi Veteriner Fakültesi Dergisi, v. 13, p. 165-170, 2007.

MOURA, A.B.; OSAKI, S.C; ZULPO, D.L. et al. Ocorrência de anticorpos contra Toxoplasma gondii em suínos e ovinos abatidos no município de Guarapuava, PR, Brasil. Revista Brasileira de Parasitologia Veterinária, v. 16, n. 1, p. 54-56, 2007.

NAVARRO, I.T.; VIDOTTO, O.; GIRALDI, N. et al. Toxoplasma gondii isolamento a partir de carne e cérebro de suínos comercializados na região de Londrina - PR. Semina. Ciências Agrárias, v. 13, n. 1, p. 32 a 34. 1992.

REGULAMENTO DA INSPEÇÃO INDUSTRIAL E SANITÁRIA DE PRODUTOS DE ORIGEM ANIMAL RIISPOA. 1952. Disponível em: $<$ http://www.agricultura.gov.br/arg editor /file/Aniamal/MercadoInterno/Requisitos/ Regulamentolnspecaolndustrial.pdf $>$ : Acesso em: 25/07/2015.

RENOINER, E.I.M.; SIQUEIRA, A.A.; GÁRCIA, M.H. et al. Surto de toxoplasmose adquirida, Anápolis-GO, fevereiro de 2006. Boletim Eletrônico Epidemiológico, v. 7, n. 8, p. 1-6, 2007. Disponível em: $<$ http://bvsms.saude.gov.br/bvs/periodic os/boletim eletronico epi ano07 n08.p df>. Acesso em: 20/07-2015.

SAMBROOK, J.; RUSSELL, D. W. Molecular cloning: A laboratory manual. $3^{\text {rd }}$ ed. New York: CSHL Press, 2001. $2100 \mathrm{p}$.
SAKATA, F.B.L.S.; BELATTO, V.; SARTOR, A.M. et al. Toxoplasma gondii antibodies sheep in Lages, Santa Catarina, Brazil, and comparison using IFA and ELISA. Revista Brasileira de Parasitologia Veterinária, v. 21, n.3, p. 196-200, 2012.

TREVISANI, N. Genotipagem de isolados de Toxoplasma gondii obtidos de Gallus gallus naturalmente infectados no estado de Santa Catarina. 2013. Lages, $51 \mathrm{f}$. Dissertação (Mestrado em Ciência Animal) - Curso de Pós Graduação em Ciência Animal, Universidade do Estado de Santa Catarina.

TSUTSUI, V.S.; FREIRE, R.L.; GÁRCIA, J.L. et al. Detection of Toxoplasma gondii by PCR and mouse bioassay in commercial cuts of pork from experimentally infected pigs. Arquivo Brasileiro de Medicina Veterinária e Zootecnia, v. 59, n. 1, p. 30-34, 2007.

YILDIZ, K.; KUL, O.; GÖKPINAR, S. et al. The relationship between seropositivity and tissue cysts in sheep naturally infected with Toxoplasma gondii. Turkish Journal of Veterinary and Animal Sciences, v. 38, p. 169175, 2014. 